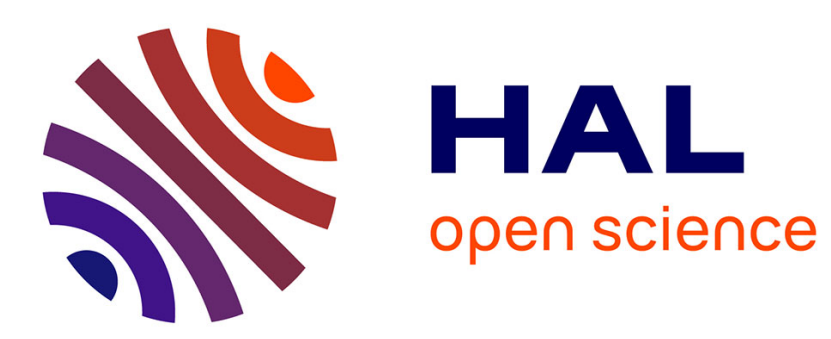

\title{
A Family of Rhodium(I) NHC Chelates Featuring O-containing Tethers for Catalytic Tandem Alkene Isomerization-Hydrosilylation
}

Ravi Srivastava, Martin Jakoobi, Chloé Thieuleux, Elsje Alessandra Quadrelli, Clément Camp

\section{To cite this version:}

Ravi Srivastava, Martin Jakoobi, Chloé Thieuleux, Elsje Alessandra Quadrelli, Clément Camp. A Family of Rhodium(I) NHC Chelates Featuring O-containing Tethers for Catalytic Tandem Alkene Isomerization-Hydrosilylation. Dalton Transactions, 2020, 10.1039/D0DT03698F . hal-03015981

\section{HAL Id: hal-03015981 \\ https://hal.science/hal-03015981}

Submitted on 20 Nov 2020

HAL is a multi-disciplinary open access archive for the deposit and dissemination of scientific research documents, whether they are published or not. The documents may come from teaching and research institutions in France or abroad, or from public or private research centers.
L'archive ouverte pluridisciplinaire $\mathbf{H A L}$, est destinée au dépôt et à la diffusion de documents scientifiques de niveau recherche, publiés ou non, émanant des établissements d'enseignement et de recherche français ou étrangers, des laboratoires publics ou privés. 
Received 00th January 20xx, Accepted 00th January 20xx DOI: $10.1039 / x 0 \times x 00000 x$

\title{
A Family of Rhodium(I) NHC Chelates Featuring O-containing Tethers for Catalytic Tandem Alkene Isomerization- Hydrosilylation
}

\author{
Ravi Srivastava, ${ }^{a}$ Martin Jakoobi, ${ }^{a}$ Chloé Thieuleux, ${ }^{a}$ Elsje Alessandra Quadrelli, ${ }^{a}$ and Clément \\ Camp*a
}

\begin{abstract}
The rhodium complex $\mathrm{Rh}(\mathrm{HL})(\mathrm{COD}) \mathrm{Cl}, \mathbf{1}$, $\mathrm{L}$ being a functionalized $\mathrm{N}$-heterocyclic carbene (NHC) ligand with an oxygencontaining pendant arm, has been used as the entry point to synthesize a series of neutral and cationic $\mathrm{Rh}(\mathrm{I}) \mathrm{O}, \mathrm{C}$ chelates. While the Rh-carbene interaction is similar in all these 16-electron complexes, structural analysis reveals that the strength of the Rh-O bond is greatly affected by the nature of the $\mathrm{O}$-donor: $\mathrm{R}-\mathrm{O}>\mathrm{R}-\mathrm{OH}>\mathrm{R}-\mathrm{OBF}$. These subtle changes in the nature of the O-containing tether are found to be responsible for large differences in the alkene hydrosilylation catalytic activity of these compounds: the stronger the Rh-O interaction, the better the catalytic performances. The most active catalyst, $[R h(L)(C O D)], 2$, demonstrated good catalytic activity under mild reaction conditions for the hydrosilylation of a range of alkene substrates with the industrially relevant non-activated tertiary silane, 1,1,1,3,5,5,5-heptamethyltrisiloxane (MD $\left.{ }^{\mathrm{H}} \mathrm{M}\right)$. Furthermore, this complex is an effective catalyst for the selective remote functionalization of internal olefins at room temperature via tandem alkene isomerization-hydrosilylation.
\end{abstract}

\section{Introduction}

Linear $\alpha$-olefins are feedstocks of high industrial relevance, which are used as high-value intermediates for the manufacture of detergents, lubricants and polymers. Industrially, linear alpha olefins are produced mainly by dehydrogenation of alkanes from thermal cracking/reforming of oil or by oligomerization of ethylene. However, both processes yield mixtures of products, including a non-negligible amount of internal linear olefins, either directly in high-temperature dehydrogenation processes, or indirectly in the case of ethylene oligomerization..$^{1,2}$ The valorization of mixtures of internal olefins through the use of transition metal catalysts can improve the olefin feedstock pool, yet classical methods for the valorization of these substrates generally leads to the formation of branched products of lower value or suffer from poor atom economy. To circumvent these issues, elegant tandem catalytic approaches were developed through isomerization of the internal alkene moiety into a distribution of positional isomers, combined with selective, irreversible functionalization of the $\alpha$-olefins yielding the desired linear functionalized products..$^{3,4}$

Alkene hydrosilylation, i.e. the addition of a hydrosilane onto an alkene, is a pertinent choice for such latter irreversible functionalization due to its high industrial relevance. Currently the silicone industry produces 2 billion tons of products/year for

\footnotetext{
a. Université de Lyon, Institut de Chimie de Lyon, C2P2 UMR 5265 CNRS-UCBL-CPE Lyon, 43 Bd du 11 Novembre 1918, F-69616 Villeurbanne, France. clement.camp@univ-lyon1.fr

Electronic Supplementary Information (ESI) available: [NMR and IR spectra of new complexes and compounds, kinetic profiles]. See DOI: 10.1039/x0xx00000x
}

a wide range of applications. ${ }^{5,6}$ Numerous $\alpha$-olefin hydrosilylation catalysts have been developed, yet these catalysts are generally unreactive towards internal olefins under classical reaction conditions. Recently, a few examples of tandem isomerization-hydrosilylation of internal olefins promoted by a single or a dual metal catalytic system have emerged in the literature. ${ }^{7-17}$ These pioneering studies are very promising, yet there is still room for improvement to strive toward ideal catalytic systems working under mild conditions, with non-activated silanes, no additives, low metal loadings, and featuring large substrate scopes without selectivity issues. This encouraged us to investigate new catalytic systems for the catalytic tandem isomerization-hydrosilylation of internal alkenes.

NHC ligands currently play a ubiquitous role in organometallic chemistry, including for the development of novel alkene hydrosilylation catalysts. ${ }^{18-24}$ We recently developed a new functionalized $\mathrm{N}$-heterocyclic carbene (NHC) ligand with an oxygen-containing pendant arm and demonstrated its interest to prepare a range of monometallic and heterobimetallic complexes. ${ }^{25-28}$ Here, we use this ligand platform to generate a family of $\mathrm{Rh}(\mathrm{I}) \mathrm{O}, \mathrm{C}$ chelates and explore their catalytic potential in alkene hydrosilylation and in tandem alkene isomerization/hydrosilylation reactions.

\section{Experimental}

\section{General considerations}

The syntheses and manipulations described below were performed using an MBraun inert atmosphere glovebox under 
an atmosphere of purified argon $\left(<1 \mathrm{ppm} \mathrm{O}_{2} / \mathrm{H}_{2} \mathrm{O}\right)$. Glassware and cannulae were stored in an oven at $\sim 110{ }^{\circ} \mathrm{C}$ for at least 12 $\mathrm{h}$ prior to use. Pentane, diethylether and tetrahydrofuran (THF) were purified by passage through a column of activated alumina, dried over $\mathrm{Na}$ /benzophenone, vacuum-transferred to a storage flask and freeze-pump-thaw degassed prior to use. Deuterated THF (THF- $d_{8}$ ) was dried over $\mathrm{Na} /$ benzophenone, vacuum-transferred to a storage flask and freeze-pump-thaw degassed prior to use. Dichloromethane and $\mathrm{CDCl}_{3}$ were dried over $\mathrm{CaH}_{2}$ and then vacuum-transferred to a storage flask and freeze-pump-thaw degassed before use. Compounds $\mathrm{Rh}(\mathrm{HL})(\mathrm{COD}) \mathrm{Cl}(\mathbf{1} \text {, Scheme } 1)^{26}$ and $\mathrm{Ta}\left(\mathrm{CH}^{t} \mathrm{Bu}\right)\left(\mathrm{CH}_{2}{ }^{t} \mathrm{Bu}\right)_{3}{ }^{29}$ were prepared using literature procedures. All other reagents were acquired from commercial sources and used as received.

\section{Synthetic procedures}

Synthesis of 2. A colorless THF solution $(6 \mathrm{~mL})$ of KHMDS ( $47 \mathrm{mg}, 0.24 \mathrm{mmol}, 1.0$ eq.) was added dropwise to a yellow THF solution (16 mL) of compound 1 (121 mg, $0.24 \mathrm{mmol}$, 1.0 eq.) under stirring. The yellow reaction mixture was stirred at room temperature for an extra $1 \mathrm{~h}$. The crude reaction was evaporated to dryness to give a yellow powder. The resulting solid was then dissolved in a minimum amount of THF $(4 \mathrm{~mL})$ and filtered. The filtrate was layered with pentane $(10 \mathrm{~mL})$ and stored at $-40{ }^{\circ} \mathrm{C}$. The thus obtained shiny rectangular shaped yellow crystals were recovered and dried in vacuo to yield complex $[\mathrm{Rh}(\mathrm{HL})(\mathrm{COD})$ ], 2 (70 mg, $0.15 \mathrm{mmol}, 63 \%$ ). Single crystals suitable for $\mathrm{X}$-Ray diffraction were grown similarly. Complex $\mathbf{2}$ can be synthesized from $\mathbf{3}$ using the exact same synthetic procedure, with analogous performances. ${ }^{1} \mathrm{H}$ NMR $\left(500 \mathrm{MHz}, \mathrm{CDCl}_{3}, 296 \mathrm{~K}\right) \delta 6.97\left(\mathrm{~s}, 2 \mathrm{H}, \mathrm{m}-\mathrm{CH}_{\mathrm{mes}}\right), 6.89\left(\mathrm{~d},{ }^{3}\right)_{\mathrm{HH}}=$ $\left.1.7 \mathrm{~Hz}, 1 \mathrm{H}, \mathrm{CH}_{\text {imid }}\right), 6.64\left(\mathrm{~d}, 3_{\mathrm{HH}}=1.7 \mathrm{~Hz}, 1 \mathrm{H}, \mathrm{CH}_{\text {imid }}\right), 4.60(\mathrm{~s}, 1 \mathrm{H}$, COD), $4.05\left(\mathrm{~s}, 2 \mathrm{H}, \mathrm{NCH}_{2}\right), 2.64(\mathrm{~s}, 2 \mathrm{H}, \mathrm{COD}), 2.34(\mathrm{~s}, 3 \mathrm{H}, p-$ $\mathrm{CH}_{3 \mathrm{Mes}}$ ), 2.19 (s, 6H, o- $\mathrm{CH}_{3 \mathrm{Mes}}$ ), 2.15-2.10 (br m, 2H, COD), 2.061.98 (br m, 2H, COD), 1.72-1.62 (br m, 4H, COD), 0.99 (s, 6H, $\left.\mathrm{CH}_{3}\right) .{ }^{13} \mathrm{C}\left\{{ }^{1} \mathrm{H}\right\}$ NMR $\left(125 \mathrm{MHz}, \mathrm{CDCl}_{3}, 296 \mathrm{~K}\right) \delta 179.53\left(\mathrm{~d}, J_{\mathrm{Rh}-\mathrm{C}}=\right.$ $\left.56 \mathrm{~Hz}, \mathrm{Rh}-\mathrm{C}_{\text {carbene }}\right), 138.60\left(\mathrm{C}_{\mathrm{Ar}}\right), 136.36\left(\mathrm{C}_{\mathrm{Ar}}\right), 135.55\left(\mathrm{C}_{\mathrm{Ar}}\right), 128.76$ $\left(\mathrm{CH}_{\mathrm{Ar}}\right), 121.74\left(\mathrm{CH}_{\text {imid }}\right), 120.88\left(\mathrm{CH}_{\text {imid }}\right), 97.62\left(\mathrm{~d}, J_{\mathrm{Rh}-\mathrm{C}}=8 \mathrm{~Hz}\right.$, $\left.\mathrm{CH}_{\text {COD }}\right), 67.98$ (s, THF), 67.79 (OC), $67.01\left(\mathrm{NCH}_{2}\right), 63.12$ (d, $J_{\mathrm{Rh}-\mathrm{C}}=$ $\left.13 \mathrm{~Hz}, \mathrm{CH}_{\mathrm{COD}}\right), 33.46\left(\mathrm{CH}_{2 \mathrm{COD}}\right), 29.07\left(\mathrm{CH}_{3}\right), 28.32\left(\mathrm{CH}_{2 \mathrm{COD}}\right), 25.61$ (s, THF), 21.09 (o-CH $\left.\mathrm{CH}_{3 \mathrm{Mes}}\right), 16.82\left(p-\mathrm{CH}_{3 \mathrm{Mes}}\right)$. DRIFT $\left(298 \mathrm{~K}, \mathrm{~cm}^{-1}\right)$ $3158.9\left(\mathrm{~m}, \mathrm{v}_{\mathrm{C}-\mathrm{H}}\right), 3128.4\left(\mathrm{~s}, \mathrm{v}_{\mathrm{C}-\mathrm{H}}\right), 3010.9\left(\mathrm{w}, \mathrm{v}_{\mathrm{C}-\mathrm{H}}\right), 2970.0\left(\mathrm{~s}, \mathrm{v}_{\mathrm{C}-}\right.$ H), $2957.3\left(\mathrm{~s}, \mathrm{v}_{\mathrm{C}-\mathrm{H}}\right), 2942.1\left(\mathrm{~s}, \mathrm{v}_{\mathrm{C}-\mathrm{H}}\right), 2932.1\left(\mathrm{~s}, \mathrm{v}_{\mathrm{C}-\mathrm{H}}\right), 2919.8\left(\mathrm{~s}, \mathrm{v}_{\mathrm{C}-}\right.$ H), $2907.6\left(\mathrm{~s}, \mathrm{v}_{\mathrm{C}-\mathrm{H}}\right), 2872.8\left(\mathrm{~s}, \mathrm{v}_{\mathrm{C}-\mathrm{H}}\right), 2863.0\left(\mathrm{~s}, \mathrm{v}_{\mathrm{C}-\mathrm{H}}\right), 2853.7\left(\mathrm{~m}, \mathrm{v}_{\mathrm{C}-}\right.$ H), $2925.6\left(\mathrm{~s}, \mathrm{v}_{\mathrm{C}-\mathrm{H}}\right), 1641.4(\mathrm{w}), 1538.5(\mathrm{~m}), 1519.8(\mathrm{w}), 1492.7$ $(\mathrm{s}), 1466.8(\mathrm{~s}), 1448.8(\mathrm{~m}), 1443.0(\mathrm{~m}), 1403.9(\mathrm{~s}), 1384.7(\mathrm{~s})$, $1362.2(\mathrm{~s}), 1344.3(\mathrm{~m}), 1322.3(\mathrm{~m}), 1271.1(\mathrm{~s}), 1214.2(\mathrm{~s}), 1204.6$ (s), $1175.5(\mathrm{~s}), 1142.4(\mathrm{~s}), 1099.9(\mathrm{w}), 1080.4(\mathrm{~m}), 1043.2(\mathrm{w})$, $1033.8(\mathrm{~m}), 1000.6(\mathrm{~m}), 982.1(\mathrm{~s}), 951.7(\mathrm{~s}), 983.9(\mathrm{~s}), 875.3(\mathrm{~m})$, $865.3(\mathrm{~m}), 851.9(\mathrm{~m}), 817.0(\mathrm{~m}), 775.3(\mathrm{~s}), 721.4(\mathrm{~s}), 717.4(\mathrm{~s})$, $694.2(\mathrm{~m}), 683.1(\mathrm{~m}), 640.6(\mathrm{~m}), 608.3(\mathrm{~m}), 596.1(\mathrm{~s}), 587.9 \mathrm{~cm}$ ${ }_{1}^{1}$ (s). Elemental analysis calcd (\%) for $\mathrm{C}_{24} \mathrm{H}_{33} \mathrm{~N}_{2} \mathrm{ORh}$ : $\mathrm{C} 61.52, \mathrm{H}$ 7.10, N 5.98; found: C 61.47, H 7.24, N 5.93.

Synthesis of 3. In the dark, silver tetrafluoroborate $(185 \mathrm{mg}$, $0.95 \mathrm{mmol}, 1.0$ eq.) was added to a $10 \mathrm{~mL}$ THF solution of compound 1 ( $480 \mathrm{mg}, 0.95 \mathrm{mmol}, 1.0$ eq.). The formation of a white precipitate was observed. The reaction mixture was stirred for $1 \mathrm{~h}$ at room temperature. The precipitate was removed by filtration and the resulting yellow filtrate was concentrated to $3 \mathrm{~mL}$, filtered again and stored at $-40{ }^{\circ} \mathrm{C}$ for 12 $\mathrm{h}$. This yielded yellow crystals which were recovered and dried in vacuo to give $[\mathrm{Rh}(\mathrm{HL})(\mathrm{COD})]\left[\mathrm{BF}_{4}\right], 3$, as a yellow crystalline solid (408 mg, $0.73 \mathrm{mmol}, 77 \%$ ). Single crystals suitable for $X$ Ray diffraction were grown similarly. ${ }^{1} \mathrm{H} \mathrm{NMR}\left(400 \mathrm{MHz}, \mathrm{CDCl}_{3}\right.$, $296 \mathrm{~K}) \delta 7.08\left(\mathrm{~d},{ }^{3} \mathrm{~J}_{\mathrm{HH}}=1.8 \mathrm{~Hz}, 1 \mathrm{H}, \mathrm{CH}_{\text {imid }}\right), 7.03\left(\mathrm{~s}, 2 \mathrm{H}, \mathrm{m}-\mathrm{CH}_{\text {mes }}\right)$, $6.78\left(\mathrm{~d}, 3^{3} \mathrm{HH}_{\mathrm{HH}}=1.8 \mathrm{~Hz}, 1 \mathrm{H}, \mathrm{CH}_{\text {imid }}\right), 5.75(\mathrm{~s}, 1 \mathrm{H}, \mathrm{OH}), 4.84(\mathrm{~s}, 2 \mathrm{H}$, $\mathrm{COD}$ ), 4.33 (s, $2 \mathrm{H}, \mathrm{NCH}_{2}$ ), 3.17-3.12 (br m, 2H, COD), 2.37 (s, 3H, $p-\mathrm{CH}_{3 \mathrm{Mes}}$ ), 2.29-2.19 (br m, 2H, COD), 2.16 (s, 6H, o- $\mathrm{CH}_{3 \mathrm{Mes}}$ ), 2.05-1.95 (br m, 2H, COD), 1.81-1.73 (br m, 2H, COD), 1.70-1.63 (br m, 2H, COD), $1.30\left(\mathrm{~s}, 6 \mathrm{H}, \mathrm{CH}_{3}\right) .{ }^{13} \mathrm{C}\left\{{ }^{1} \mathrm{H}\right\} \mathrm{NMR}\left(100 \mathrm{MHz}^{\mathrm{C} C D C l}{ }_{3}\right.$, 296 K) $\delta 174.26$ (d, $J_{\text {Rh-C }}=52 \mathrm{~Hz}$; Rh-C carbene), $139.88\left(\mathrm{C}_{\mathrm{Ar}}\right), 135.42$ $\left(\mathrm{C}_{\mathrm{Ar}}\right), 135.21\left(\mathrm{C}_{\mathrm{Ar}}\right), 129.37\left(\mathrm{CH}_{\mathrm{Ar}}\right), 123.36\left(\mathrm{CH}_{\text {imid }}\right), 122.92\left(\mathrm{CH}_{\text {imid }}\right)$, $99.95\left(\mathrm{~d}, J_{\mathrm{Rh}-\mathrm{C}}=7 \mathrm{~Hz}, \mathrm{CH}_{\mathrm{COD}}\right), 72.25$ (OC), 68.14 (THF), 67.91 (d, $J_{\mathrm{Rh}-\mathrm{C}}=16 \mathrm{~Hz}, \mathrm{CH}$ COD $), 61.33\left(\mathrm{NCH}_{2}\right), 32.97\left(\mathrm{CH}_{2 \mathrm{COD}}\right), 28.10\left(\mathrm{CH}_{3}\right)$, 25.78 (THF), 24.95 ( $\left.\mathrm{CH}_{2 \mathrm{COD}}\right), 21.26$ (o- $\left.\mathrm{CH}_{3 \mathrm{Mes}}\right), 18.51$ ( $p$ - $\left.\mathrm{CH}_{3 \mathrm{Mes}}\right)$. ${ }^{19} \mathrm{~F}\left\{{ }^{1} \mathrm{H}\right\} \mathrm{NMR}\left(376 \mathrm{MHz}, \mathrm{CDCl}_{3}, 296 \mathrm{~K}\right) \delta-150.27\left(\mathrm{~s},{ }^{10} \mathrm{BF}_{4}^{-}\right)$, $150.32\left(\mathrm{~s},{ }^{11} \mathrm{BF}_{4}{ }^{-}\right) .{ }^{11} \mathrm{~B}\left\{{ }^{1} \mathrm{H}\right\} \mathrm{NMR}\left(96 \mathrm{MHz}, \mathrm{CDCl}_{3}, 296 \mathrm{~K}\right) \delta-1.05$ (s). DRIFT (298 K, cm $\left.\mathrm{cm}^{-1}\right) 3349.4\left(\mathrm{~s}, \mathrm{v}_{\mathrm{O}-\mathrm{H}}\right), 3157.7\left(\mathrm{~m}, \mathrm{v}_{\mathrm{C}-\mathrm{H}}\right), 3132.2$ $\left(\mathrm{m}, \mathrm{v}_{\mathrm{C}-\mathrm{H}}\right), 2973.5\left(\mathrm{~s}, \mathrm{v}_{\mathrm{C}-\mathrm{H}}\right), 2935.1\left(\mathrm{~s}, \mathrm{v}_{\mathrm{C}-\mathrm{H}}\right), 2922.9\left(\mathrm{~s}, \mathrm{v}_{\mathrm{C}-\mathrm{H}}\right), 2874.3$ $\left(\mathrm{s}, \mathrm{v}_{\mathrm{C}-\mathrm{H}}\right), 2829.3\left(\mathrm{~s}, \mathrm{v}_{\mathrm{C}-\mathrm{H}}\right), 1608.7(\mathrm{w}), 1490.1(\mathrm{~s}), 1450.9(\mathrm{~s}), 1412.7$ (s), $1392.0(\mathrm{~s}), 1373.3(\mathrm{~m}), 1348.5(\mathrm{w}), 1305.3(\mathrm{w}), 1259.1(\mathrm{w})$, $1224.6(\mathrm{~m}), 1192.4(\mathrm{~m}), 1142.7(\mathrm{~s}), 1111.8(\mathrm{~s}), 1084.1(\mathrm{~s}), 967.9$ (s), $912.9(\mathrm{w}), 887.2(\mathrm{~m}), 865.6(\mathrm{~m}), 775.7(\mathrm{~m}), 762.5(\mathrm{~s}), 703.2$ $(\mathrm{w}), 587.2(\mathrm{w}), 518.8(\mathrm{~m}), 494.2 \mathrm{~cm}^{-1}(\mathrm{~m})$. Elemental analysis calcd (\%) for $\mathrm{C}_{24} \mathrm{H}_{34} \mathrm{~N}_{2} \mathrm{ORhBF}_{4} \mathrm{C} 51.82, \mathrm{H}$ 6.16, N 5.04; found: C 51.93, H 6.25, N 5.12.

Synthesis of 4. A light yellow suspension of compound 3 (250 $\mathrm{mg}, 0.45 \mathrm{mmol}, 1.0$ eq.) in $16 \mathrm{~mL}$ THF was added dropwise to a stirring dark orange solution of $\mathrm{Ta}(\mathrm{CH} t \mathrm{Bu})\left(\mathrm{CH}_{2} t \mathrm{Bu}\right)_{3}(208 \mathrm{mg}$, $0.45 \mathrm{mmol}, 1.0$ eq.) in THF $(8 \mathrm{~mL})$. The reaction mixture was stirred at room temperature for $6.5 \mathrm{~h}$. After that the solution was concentrated to half, filtered and stored at $-40{ }^{\circ} \mathrm{C}$ for $12 \mathrm{~h}$. The resulting yellow solid which was recovered and dried in vacuo to give complex $\left[\mathrm{Rh}\left(\mathrm{L} \cdot \mathrm{BF}_{3}\right)(\mathrm{COD})\right], 4(115 \mathrm{mg}, 0.21 \mathrm{mmol}$, $48 \%)$. The fate of the Ta-based coproduct was further investigated by solution state NMR as discussed in the results and discussion section. Single crystals of $\mathbf{4}$ suitable for X-Ray diffraction were grown by the slow diffusion of diethylether ( 5 $\mathrm{mL}$ ) into a concentrated dichloromethane solution of $4(2 \mathrm{~mL})$ at $-40{ }^{\circ} \mathrm{C} .{ }^{1} \mathrm{H}$ NMR $\left(300 \mathrm{MHz}, \mathrm{CDCl}_{3}, 296 \mathrm{~K}\right) \delta 7.11(\mathrm{~s}, 1 \mathrm{H}, \mathrm{m}-$ $\left.\mathrm{CH}_{\text {mes }}\right), 7.03\left(\mathrm{~d}, 3^{3} \mathrm{HH}_{1}=1.8 \mathrm{~Hz}, 1 \mathrm{H}, \mathrm{CH}_{\text {imid }}\right), 6.91\left(\mathrm{~s}, 1 \mathrm{H}, \mathrm{m}-\mathrm{CH}_{\text {mes }}\right)$, $6.73\left(\mathrm{~d},{ }^{3} \int_{\mathrm{HH}}=1.8 \mathrm{~Hz}, 1 \mathrm{H}, \mathrm{CH}_{\text {imid }}\right), 5.50\left(\mathrm{~d},{ }^{2} J_{\mathrm{HH}}=14 \mathrm{~Hz}, 1 \mathrm{H}, \mathrm{NCH}_{2}\right)$, $5.40(\mathrm{~s}, 1 \mathrm{H}, \mathrm{COD}), 5.23(\mathrm{~s}, 1 \mathrm{H}, \mathrm{OH}), 5.27(\mathrm{~s}, 1 \mathrm{H}, \mathrm{COD}), 3.95$ (d, $\left.{ }^{2} J_{\mathrm{HH}}=14 \mathrm{~Hz}, 1 \mathrm{H}, \mathrm{NCH}_{2}\right), 3.35(\mathrm{~s}, 1 \mathrm{H}, \mathrm{COD}), 2.65$ (s, 1H, COD), 2.48 (br s, $1 \mathrm{H}, \mathrm{COD}$ ), 2.37 (s, 3H, $p-\mathrm{CH}_{3 \mathrm{Mes}}$ ), 2.35 (s, 3H, o- $\mathrm{CH}_{3 \mathrm{Mes}}$ ), 2.04-1.99 (br m, 4H, COD), 1.88 (s, 3H, o- $\mathrm{CH}_{3 \mathrm{Mes}}$ ), 1.76 (br m, $1 \mathrm{H}$, COD), $1.61\left(\mathrm{~s}, 3 \mathrm{H}, \mathrm{CH}_{3}\right), 1.44$ (br m, 2H, COD), $1.21\left(\mathrm{~s}, 3 \mathrm{H}, \mathrm{CH}_{3}\right)$. ${ }^{1} \mathrm{H}$ NMR $\left(300 \mathrm{MHz}, \mathrm{THF}-d_{8}, 296 \mathrm{~K}\right) \delta 7.34\left(\mathrm{~d},{ }^{3} \int_{\mathrm{HH}}=1.8 \mathrm{~Hz}, 1 \mathrm{H}\right.$, $\left.\mathrm{CH}_{\text {imid }}\right), 7.14\left(\mathrm{~s}, 1 \mathrm{H}, \mathrm{m}-\mathrm{CH}_{\text {mes }}\right), 7.00$ (d, $\left.{ }^{3} \mathrm{H}_{\mathrm{HH}}=1.8 \mathrm{~Hz}, 1 \mathrm{H}, \mathrm{CH}_{\text {imid }}\right)$, $6.94\left(\mathrm{~s}, 1 \mathrm{H}, \mathrm{m}-\mathrm{CH}_{\mathrm{mes}}\right), 5.38$ (br m, 2H, COD), $5.33\left(\mathrm{~m}, 1 \mathrm{H}, \mathrm{NCH}_{2}\right)$, 5.27 (br m, $1 \mathrm{H}, \mathrm{COD}), 4.11$ (d, ${ }^{2} \mathrm{H}_{\mathrm{HH}}=18 \mathrm{~Hz}, 1 \mathrm{H}, \mathrm{NCH}_{2}$ ), 3.34 (br s, $1 \mathrm{H}, \mathrm{COD}$ ), 2.62 (br s, 1H, COD), 2.50 (br s, 1H, COD), 2.36 (s, 3H, 


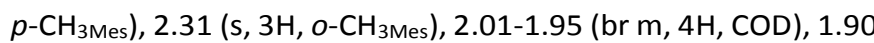
(s, 3H, o- $\mathrm{CH}_{3 \mathrm{Mes}}$ ), 1.53 (s, 3H, $\left.\mathrm{CH}_{3}\right), 1.44$ (br m, 2H, COD), 1.12 (s, $\left.3 \mathrm{H}, \mathrm{CH}_{3}\right) \cdot{ }^{13} \mathrm{C}\left\{{ }^{1} \mathrm{H}\right\}$ NMR $\left(125 \mathrm{MHz}, \mathrm{THF}-\mathrm{d}_{8}, 296 \mathrm{~K}\right) \delta 178.91\left(\mathrm{~d}, J_{\mathrm{Rh}-}\right.$ $\left.\mathrm{c}=51 \mathrm{~Hz}, \mathrm{Rh}-\mathrm{C}_{\text {carbene }}\right), 139.42\left(\mathrm{C}_{\mathrm{Ar}}\right), 137.71\left(\mathrm{C}_{\mathrm{Ar}}\right), 136.40\left(\mathrm{C}_{\mathrm{Ar}}\right)$, $134.79\left(\mathrm{C}_{\mathrm{Ar}}\right), 130.04\left(\mathrm{CH}_{\mathrm{Ar}}\right), 128.88\left(\mathrm{CH}_{\mathrm{Ar}}\right), 123.39\left(\mathrm{CH}_{\text {imid }}\right)$, $123.10\left(\mathrm{CH}_{\text {imid }}\right), 102.41$ (d, $\left.J_{\text {Rh-C }}=90 \mathrm{~Hz}, \mathrm{COD}\right), 72.09$ (OC), 64.98 $\left(\mathrm{s}, \mathrm{N}-\mathrm{CH}_{2}\right), 63.21\left(\mathrm{~d}, J_{\mathrm{Rh}-\mathrm{C}}=17 \mathrm{~Hz}, \mathrm{CH}_{\mathrm{COD}}\right), 61.73\left(\mathrm{~d}, J_{\mathrm{Rh}-\mathrm{C}}=17 \mathrm{~Hz}\right.$,

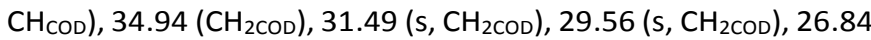
(s, $\mathrm{CH}_{2 \mathrm{COD}}$ ), 26.34 (s, $\left.\mathrm{CH}_{3}\right), 24.50$ (s, $\left.\mathrm{CH}_{3}\right), 20.90$ (o- $\left.\mathrm{CH}_{3 \mathrm{Mes}}\right), 19.25$ $\left(o-\mathrm{CH}_{3 \mathrm{Mes}}\right), 17.60$ ( $p$ - $\left.\mathrm{CH}_{3 \mathrm{Mes}}\right) .{ }^{19} \mathrm{~F}\left\{{ }^{1} \mathrm{H}\right\}$ NMR $\left(282 \mathrm{MHz}, \mathrm{CDCl}_{3}, 296\right.$ K) $\delta-141.51\left(q,{ }^{2} J_{\mathrm{B}-\mathrm{F}}=10 \mathrm{~Hz}\right) .{ }^{11} \mathrm{~B}\left\{{ }^{1} \mathrm{H}\right\} \mathrm{NMR}\left(96 \mathrm{MHz}, \mathrm{CDCl}_{3}, 296\right.$ K) $\delta-0.53\left(q,{ }^{2} J_{F-B}=10 \mathrm{~Hz}\right)$. DRIFT $\left(298 \mathrm{~K}, \mathrm{~cm}^{-1}\right) 3172.2\left(\mathrm{~m}, \mathrm{v}_{\mathrm{C}-\mathrm{H}}\right)$, 3142.7 (m, $\left.v_{C-H}\right), 2971.0\left(\mathrm{~s}, v_{C-H}\right), 2930.0\left(\mathrm{~s}, v_{C-H}\right), 2872.3\left(\mathrm{~m}, v_{C}\right.$ H), $2829.2\left(\mathrm{~m}, \mathrm{v}_{\mathrm{C}-\mathrm{H}}\right), 1608.7(\mathrm{w}), 1489.1(\mathrm{~s}), 1474.7(\mathrm{w}), 1437.7$ (m), 1412.9 (s), $1385.6(\mathrm{~s}), 1366.6(\mathrm{w}), 1350.2(\mathrm{w}), 1333.3(\mathrm{w})$, $1306.1(w), 1271.4(w), 1236.9(\mathrm{~m}), 1224.7(\mathrm{~s}), 1186.1(\mathrm{~s})$, $1146.1(\mathrm{~s}), 1091.7(\mathrm{~s}), 1057.7(\mathrm{~s}), 1039.1(\mathrm{~s}), 984.2(\mathrm{~s}), 968.5(\mathrm{~s})$ $915.6(\mathrm{~s}), 866.0(\mathrm{~m}), 812.3(\mathrm{w}), 751.6(\mathrm{~m}), 727.6(\mathrm{~m}), 698.9(\mathrm{~m})$, $587.1(\mathrm{w}), 509.5 \mathrm{~cm}^{-1}(\mathrm{~m})$. Elemental analysis calcd (\%) for $\mathrm{C}_{24} \mathrm{H}_{33} \mathrm{~N}_{2} \mathrm{ORhBF}_{3} \mathrm{C}$ 53.72, H 6.20, N 5.22; found: C 53.63, H 6.30, N 5.14 .

\section{Catalysis}

Catalyst screening. The rhodium catalyst $(0.0045 \mathrm{mmol}, 1 \mathrm{~mol} \%$ per Rh-atom) was dissolved in a $0.5 \mathrm{~mL}$ THF- $d_{8}$ solution containing 3,3-dimethyl-1-butene ( $0.45 \mathrm{mmol}, 1.0$ equiv.), $\mathrm{MD}^{\mathrm{H} M}(0.45 \mathrm{mmol}, 1.0$ equiv.) and 1,2,4,5-tetramethylbenzene ( $0.45 \mathrm{mmol}, 1.0$ equiv., internal standard). The reaction was monitored by ${ }^{1} \mathrm{H}$ NMR at room temperature until completion (conversion, yield and mass balance were determined by integration of the ${ }^{1} \mathrm{H}$ NMR signals).

Terminal alkene hydrosilylation scope. A stock solution of $\mathbf{2}$ ( $500 \mu \mathrm{L}, 0.1 \mathrm{~mol} \%$ of 2 ) was added to a solution containing the terminal alkene $(0.45 \mathrm{mmol}, 1.0$ equiv., see Table 4 for list of alkenes investigated), $\mathrm{MD}^{\mathrm{H} M}(122 \mu \mathrm{L}, 0.45 \mathrm{mmol}, 1.0$ equiv.) and mesitylene (63 $\mu \mathrm{L}, 0.45 \mathrm{mmol}, 1.0$ equiv., internal standard). The reaction was left to stir at $1000 \mathrm{rpm}$ at room temperature and the reaction progress was monitored by GC after 5 and $24 \mathrm{~h}$ (conversion, yield and mass balance determined by GC). Reactions using 1 mol\% of catalyst 2 (2.1 $\mathrm{mg}, 0.045 \mathrm{mmol}$ in $500 \mu \mathrm{L}$ of THF) were carried out similarly to reactions at $0.1 \mathrm{~mol} \%$ of catalyst loading.

Tandem isomerization/hydrosilylation catalysis. All the reactions with internal alkenes were carried out similarly to those using the terminal alkene hydrosilylation procedure at 1.0 mol\% of 2.

\section{Characterizations}

NMR spectroscopy. Multinuclei NMR spectra were recorded on Bruker AV-300, AVQ-400 and AV-500 spectrometers. ${ }^{1} \mathrm{H}$ and ${ }^{13} \mathrm{C}$ chemical shifts $(\delta)$ are given in parts per million (ppm) referenced to the appropriate residual solvent peak $\left({ }^{1} \mathrm{H} N M R\right.$ : $\mathrm{CDCl}_{3}$ at $7.26 \mathrm{ppm}$, THF-d $\mathrm{d}_{8}$ at $3.58 \mathrm{ppm} .{ }^{13} \mathrm{C} \mathrm{NMR:}^{\mathrm{CDCl}} 3$ at 77.16 ppm, THF- $\mathrm{d}_{8}$ at $\left.67.21 \mathrm{ppm}\right) .{ }^{11} \mathrm{~B}$ and ${ }^{19} \mathrm{~F}$ NMR chemical shifts are reported relative to $\mathrm{BF}_{3} \cdot \mathrm{OEt}_{2}$ set at $0.00 \mathrm{ppm} .{ }^{29} \mathrm{Si} \mathrm{NMR}$ chemical shifts are reported relative to $\left(\mathrm{Me}_{3} \mathrm{Si}\right)_{2} \mathrm{O}$ set at $7.2 \mathrm{ppm} .{ }^{1} \mathrm{H}$ and ${ }^{13} \mathrm{C}$ NMR assignments were routinely confirmed by ${ }^{1} \mathrm{H}-{ }^{1} \mathrm{H}$ COSY and ${ }^{1} \mathrm{H}-{ }^{13} \mathrm{C}$ HSQC and $\mathrm{HMBC}$ experiments. 1,2,4,5tetramethylbenzene was used as internal standard to measure yields via ${ }^{1} \mathrm{H}$ NMR.

Infrared spectroscopy. Samples were prepared in a glovebox, sealed under argon in a DRIFT cell equipped with $\mathrm{KBr}$ windows and analyzed on a Nicolet 6700 FT-IR spectrometer.

Elemental analyses were performed at the School of Human Sciences, Science Center, London Metropolitan University.

Mass Spectrometry. High resolution mass spectra were measured on a Bruker QTOF Impact II at "Centre Commun de Spectrométrie de Masse" in Lyon, France.

Gas chromatography. GC analyses were performed on HP 6890 chromatograph with a HP5 (5\% of phenylmethylsiloxane) column ( $30 \mathrm{~m}$ length, $320 \mu \mathrm{m}$ of diameter, $0.25 \mathrm{~nm}$ of thickness) equipped with flame ionization detector (FID). Mesitylene was used as internal standard to measure yields via GC. At the end of reactions, the crude mixture was passed through a short plug of silica (pentane was used as eluent) to remove the catalyst. The resulting filtrate fractions were treated under reduced pressure at $50{ }^{\circ} \mathrm{C}$ to remove the volatiles (solvent and remaining starting materials), yielding clear liquid products.

X-ray Crystallography. X-ray structural determinations were performed at the "Centre de diffractométrie Henri Longchambon, Université de Lyon". A suitable crystal coated in Parabar oil was selected and mounted on a Gemini kappageometry diffractometer (Rigaku Oxford Diffraction) equipped with an Atlas CCD detector and using Mo radiation $(\lambda=0.71073$ $\AA$ A). Intensities were collected at $100 \mathrm{~K}$ or $150 \mathrm{~K}$ by means of the CrysalisPro software. Reflection indexing, unit-cell parameters refinement, Lorentz-polarization correction, peak integration and background determination were carried out with the CrysalisPro software. An analytical absorption correction was applied using the modeled faces of the crystal. ${ }^{30}$ The resulting set of hkl was used for structure determination and refinement. The structures were solved by direct methods with SIR97 ${ }^{31}$ and the least-square refinement on $F^{2}$ was achieved with the CRYSTALS software. ${ }^{32}$ All non-hydrogen atoms were refined anisotropically. The hydrogen atoms were all located in a difference map, but those attached to carbon atoms were repositioned geometrically. The $\mathrm{H}$ atoms were initially refined with soft restraints on the bond lengths and angles to regularize their geometry ( $\mathrm{C}---\mathrm{H}$ in the range 0.93-0.98 $\AA$, O--- $\mathrm{H}=0.82 \AA$ ) and $\mathrm{U}_{\text {iso }}(\mathrm{H})$ (in the range 1.2-1.5 times $\mathrm{U}_{\text {eq }}$ of the parent atom), after which the positions were refined with riding constraints. Thermal ellipsoid plots were created using Mercury supplied with Cambridge Structural Database. CCDC 2026410, 2026411 and 2026412 contain the supplementary crystallographic data for this paper. These data are provided free of charge by the Cambridge Crystallographic Data Centre. 
Table 1. X-ray crystallographic parameters for complexes 2, 3 and 4.

\begin{tabular}{|c|c|c|c|}
\hline Compound & 2 & 3 & 4 \\
\hline Formula & $\mathrm{C}_{24} \mathrm{H}_{33} \mathrm{~N}_{2} \mathrm{ORh}$ & $\mathrm{C}_{24} \mathrm{H}_{34} \mathrm{BN}_{2} \mathrm{OF}_{4} \mathrm{Rh}$ & $\mathrm{C}_{24} \mathrm{H}_{33} \mathrm{BN}_{2} \mathrm{OF}_{3} \mathrm{Rh}$ \\
\hline cryst syst & Trigonal & Monoclinic & Triclinic \\
\hline space group & $R 3$ & $\mathrm{C} 2 / \mathrm{c}$ & $P-1$ \\
\hline volume $\left(\AA^{3}\right)$ & 9813.7(19) & $5787(3)$ & $1192.33(17)$ \\
\hline $\mathrm{a}(\AA \AA)$ & $32.883(3)$ & $41.765(7)$ & $7.6521(6)$ \\
\hline$b(\AA ̊)$ & $32.883(3)$ & $7.8159(6)$ & $12.0807(9)$ \\
\hline$c(\AA ̊)$ & $10.4799(11)$ & $24.836(4)$ & $14.3701(10)$ \\
\hline$\alpha(\mathrm{deg})$ & 90 & 90 & $65.159(7)$ \\
\hline$\beta$ (deg) & 90 & $134.45(3)$ & $82.202(6)$ \\
\hline$\nu$ (deg) & 120 & 90 & $83.726(7)$ \\
\hline Z & 18 & 8 & 2 \\
\hline $\begin{array}{l}\text { formula weight } \\
\qquad(\mathrm{g} / \mathrm{mol})\end{array}$ & 468.43 & 556.25 & 536.24 \\
\hline density $\left(\mathrm{g} \mathrm{cm}^{-3}\right)$ & 1.427 & 1.277 & 1.494 \\
\hline $\begin{array}{c}\text { absorption } \\
\text { coefficient } \\
\left(\mathrm{mm}^{-1}\right)\end{array}$ & 0.80 & 0.63 & 0.76 \\
\hline$F(000)$ & 4392 & 2288 & 552 \\
\hline$\theta_{\max }\left({ }^{\circ}\right)$ & 29.615 & 29.667 & 29.704 \\
\hline temp $(\mathrm{K})$ & 100.0(1) & $150.0(1)$ & $100.0(1)$ \\
\hline $\begin{array}{l}\text { total no. } \\
\text { reflections }\end{array}$ & 16712 & 48291 & 31111 \\
\hline $\begin{array}{l}\text { unique } \\
\text { reflections } \\
{[R \text { (int)] }}\end{array}$ & 5342 [0.062] & $7556[0.056]$ & 6159 [0.0792] \\
\hline $\begin{array}{c}\text { Final } R \text { indices } \\
{[I>2 \sigma(I)]}\end{array}$ & $\begin{aligned} R 1 & =0.0753, \\
w R 2 & =0.2150\end{aligned}$ & $\begin{aligned} R 1 & =0.0533 \\
w R 2 & =0.1115\end{aligned}$ & $\begin{array}{l}R 1=0.0631, \\
w R 2=0.1314\end{array}$ \\
\hline GooF & 0.970 & 0.9663 & 1.125 \\
\hline
\end{tabular}

\section{Results and discussion}

\section{Synthesis of complexes and characterization in solution.}

The previously reported rhodium complex $\mathrm{Rh}(\mathrm{HL})(\mathrm{COD}) \mathrm{Cl}, \mathbf{1}^{26}$ coordinated by a NHC ligand featuring an oxygen-containing pendant arm (noted L), has been used as the entry point to generate a series of neutral and cationic $\mathrm{Rh}(\mathrm{I}) \mathrm{O}, \mathrm{C}$-chelates. Deprotonation of $\mathbf{1}$ with one equivalent of potassium bis(trimethylsilyl)amide (KHMDS) yields the alkoxy-NHC complex [Rh(L)(COD)], 2, in 63\% isolated yield (Scheme 1). In the ${ }^{1} \mathrm{H}$ NMR spectrum of $\mathbf{2}$, the imidazolyl backbone protons from the unsymmetrical $\mathrm{NHC}$ are observed as doublets $\left({ }^{3} \mathrm{~J}_{\mathrm{HH}}=1.7 \mathrm{~Hz}\right)$ at $\delta=6.89$ and $6.64 \mathrm{ppm}$, respectively. The $\mathrm{N}-\mathrm{CH}_{2}$ protons are equivalent and observed as a singlet at $\delta=4.05 \mathrm{ppm}$ integrating for two protons, which is indicative of fast conformational flipping of the ligand methylene bridge on the NMR timescale. As a result of ligand deprotonation, the ${ }^{1} \mathrm{H}$ NMR spectrum for 2 does not contain a resonance corresponding to the hydroxyl proton which is also verified by the absence of hydroxyl stretching frequency in IR spectroscopy (Figure S14).

The cationic rhodium analogue $[\mathrm{Rh}(\mathrm{HL})(\mathrm{COD})]\left[\mathrm{BF}_{4}\right], 3$, is isolated in $77 \%$ yield from treatment of $\mathbf{1}$ with the corresponding $\mathrm{AgBF}_{4}$ salt, as shown in Scheme 1 . The IR spectrum for complex 3 (Figure S15) displays an intense $\mathrm{V}_{\mathrm{OH}}$ signal around $3350 \mathrm{~cm}^{-1}$ which confirms the presence of the hydroxyl group. The ${ }^{1} \mathrm{H} N M R$ spectrum for compound 3 (Figure S4), displays the hydroxyl proton signal at $\delta=5.75 \mathrm{ppm}$ which is fairly downfield shifted as compared to the corresponding signal in $\mathbf{1}$ where it is observed at $\delta=3.17 \mathrm{ppm}$. This downfield shift is most likely due to a hydroxyl-metal interaction in solution. ${ }^{33-35}$ Note that binding of the hydroxyl group to $\mathrm{Rh}$ is confirmed in the solidstate (see below). As for $\mathbf{2}$, the $\mathrm{NCH}_{2}$ methylene fragment resonance in 3 is a singlet found at $\delta=4.33 \mathrm{ppm}(2 \mathrm{H})$. The presence of the $\mathrm{BF}_{4}^{-}$counter anion is confirmed by ${ }^{11} \mathrm{~B}$ and ${ }^{19} \mathrm{~F}$ NMR spectroscopies (Figures S6 and S7).

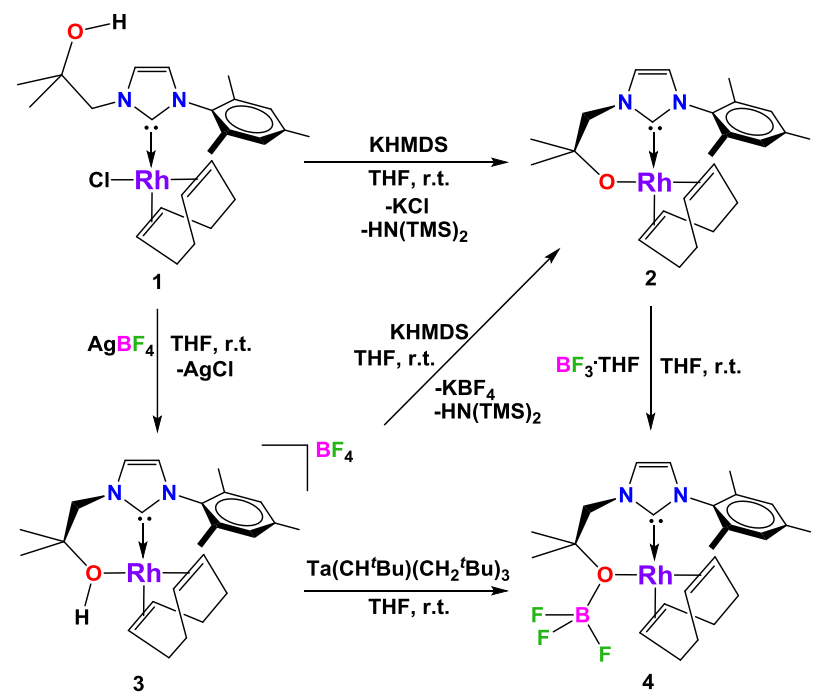

Scheme 1. Synthetic routes to the Rh-NHC complexes 1-4.

Treatment of compound $\mathbf{3}$ with 1 equivalent of KHMDS quantitatively affords compound $\mathbf{2}$, as an alternative synthetic route to $\mathbf{2}$. The latter reactivity indicates that the hydroxyl group in 3 might react with basic metal derivatives to yield heterobimetallic assemblies. Accordingly, in an attempt to synthesize a tantalum/rhodium heterobimetallic species, ${ }^{25,26,36,37}$ complex 3 was treated with 1 equivalent of $\mathrm{Ta}\left(\mathrm{CH}^{t} \mathrm{Bu}\right)\left(\mathrm{CH}_{2}{ }^{t} \mathrm{Bu}\right)_{3}$ at room temperature in THF. After reaction completion, the crude mixture was concentrated and stored at $-40{ }^{\circ} \mathrm{C}$ to yield a new product, 4 , as a yellow microcrystalline powder in $48 \%$ yield. The IR spectrum of complex 4 does not contain a hydroxyl group stretching signal (Figure S16), which shows that the site of reaction is the hydroxyl proton as anticipated. However, detailed NMR studies reveal that the obtained product is not a Ta/Rh heterobimetallic species, but rather the unexpected monometallic complex $\left[R h\left(L \cdot B F_{3}\right)(C O D)\right]$, 4 , (Scheme 1). The presence of the $\mathrm{BF}_{3}$ moiety is confirmed by the ${ }^{19} \mathrm{~F}$ NMR data for 4 which displays a signal at $\delta=-141.51$ ppm and by the ${ }^{11} \mathrm{~B}$ NMR spectrum for 4 featuring a characteristic quartet $\left({ }^{1} J_{\mathrm{B}-\mathrm{F}}=10 \mathrm{~Hz}\right)$ centered at $\delta=-0.53 \mathrm{ppm}$. As a result of borane coordination, the alkoxy-NHC ligand backbone adopts a more rigid conformation, which is reflected notably by the $\mathrm{N}-\mathrm{CH}_{2}$ methylene fragment ${ }^{1} \mathrm{H}$ NMR signal which splits into a pair of diastereotopic doublets at $\delta=5.50$ and 3.95 ppm $\left({ }^{2} J_{\mathrm{HH}}=14.0 \mathrm{~Hz}\right)$. 


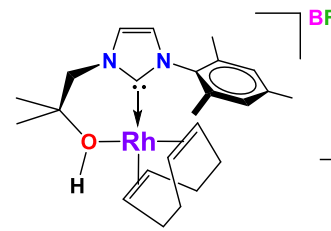

3

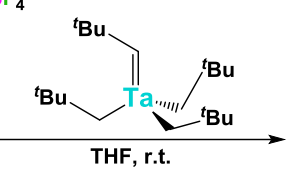

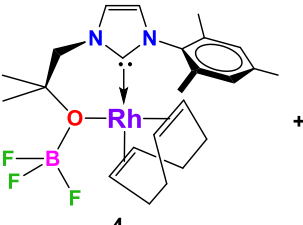

4

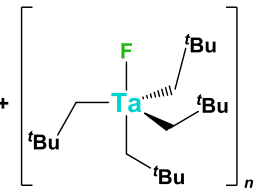

observed by NMR

Scheme 2. Proposed synthesis of compound $\mathbf{4}$ from $\mathbf{3}$ upon deprotonation and fluoride abstraction by $\mathrm{Ta}\left(\mathrm{CH}^{t} \mathrm{Bu}\right)\left(\mathrm{CH}_{2}{ }^{t} \mathrm{Bu}\right)_{3}$.

Despite the low nucleophilicity of the tetrafluoroborate anion, strong electrophiles such as early transition metal species ${ }^{38-42}$ can abstract fluoride from $\mathrm{BF}_{4}^{-} .43,44$ Here the tantalum alkyl alkylidene derivative is proposed to act both as a base to deprotonate the hydroxyl group in $\mathbf{3}$ and as an electrophile to abstract a fluoride from the $\mathrm{BF}_{4}{ }^{-}$anion. This proposal is based on NMR monitoring of the reaction, which was carried out in THF- $d_{8}$. As the reaction progressed, the ${ }^{1} \mathrm{H}$ NMR signal corresponding to the acidic hydroxyl proton in $\mathbf{3}$ disappeared, as a result of the 1,2-addition reaction with the tantalum alkylidene moiety, without the release of neopentane. This was confirmed by the disappearance of the alkylidene signal in ${ }^{1} \mathrm{H}$ NMR and ${ }^{13} \mathrm{C}$ NMR spectra. The ${ }^{19} \mathrm{~F}$ NMR spectrum of the solution displays a singlet at $\delta=73.69 \mathrm{ppm}$ (Figure S13) which is characteristic of tantalum fluorides, ${ }^{45,46}$ and corroborates the formation of a tantalum neopentyl fluoride derivative of general formula $\left[\mathrm{Ta}\left(\mathrm{CH}_{2}{ }^{t} \mathrm{Bu}\right)_{4} \mathrm{~F}\right]_{n}$. Unfortunately, multiple attempts to obtain the crystal structure of this tantalum tetraalkyl fluoride co-product failed because of the very high solubility of this species in non-polar solvents. Based on all these observations, the following reaction scheme can be proposed (Scheme 2).

Compound $\mathbf{4}$ can be seen as a boron trifluoride adduct of $\mathbf{2}$, as treatment of $\mathbf{2}$ with $\mathrm{BF}_{3} \cdot \mathrm{THF}$ (Scheme 1) cleanly leads to $\mathbf{4}$ as well (Figure S12).

\section{Comparative structural analysis}

The crystallographic structures of 2, $\mathbf{3}$ and $\mathbf{4}$ were determined by $\mathrm{X}$-ray diffraction on single crystals (Figure 1 ). The three complexes adopt a typical square planar geometry at the $\mathrm{Rh}(\mathrm{I})$ centre. The oxygen-functionalized NHC ligands interact with rhodium in a $(\mathrm{O}, \mathrm{C})$ chelate fashion to form 6-members metallacycles featuring pseudo-boat conformations. The crystal structure of 4 confirms that the $\mathrm{BF}_{3}$ moiety is bound to the oxygen atom of the chelated alkoxy group, in agreement with the NMR data.

The analysis of the Rh-O distances (Table 2) shows a strong disparity in the rhodium-oxygen interactions. The $\mathrm{Rh}-\mathrm{O}$ bond length in $\mathbf{2}(2.031(4) \AA)$ is quite short and falls in the range of reported four-coordinate rhodium(I) alkoxy bond distances. 47,48 The corresponding bond length in the cationic complex 3 $(2.152(2) \AA)$ is elongated, which is expected as a result of protonation. Noticeably, the rhodium-oxygen bond distance in $4(2.212(3) \AA)$ is much longer than in 2 but also in $\mathbf{3}$. This suggests that coordination of the strong Lewis acidic $\mathrm{BF}_{3}$ motif drastically reduces the nucleophilicity of the O-donor site of the bifunctional NHC ligand. It is also possible that this observed geometric distortion is a steric phenomenon since the $\mathrm{BF}_{3}$ group is significantly more bulky than a proton substituent.
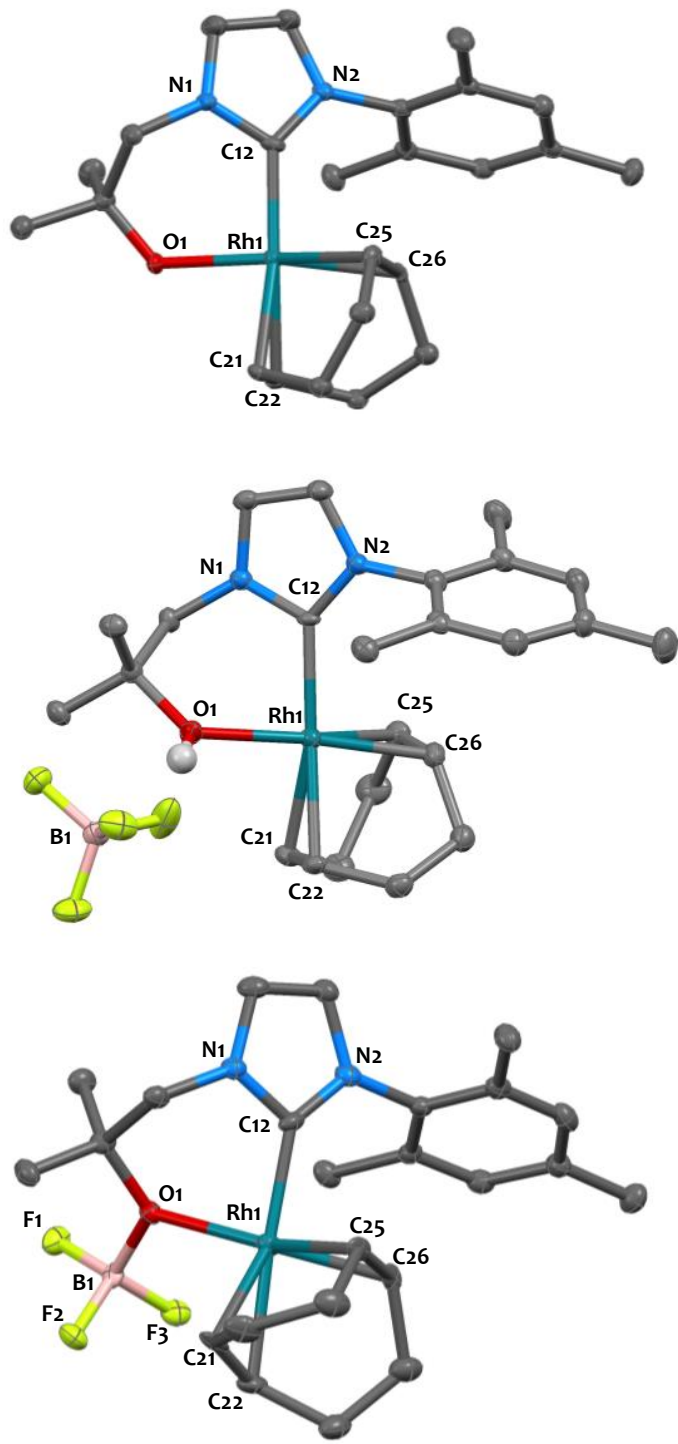

Figure 1. Solid-state molecular structures of $\mathbf{2}$ (top), $\mathbf{3}$ (middle), and $\mathbf{4}$ (bottom) (30\% probability ellipsoids). Hydrogen atoms, except that of the hydroxyl group in $\mathbf{3}$ have been omitted for clarity. Selected bond distances $(\AA)$ and angles $\left({ }^{\circ}\right)$ for 2: Rh1-01 = 2.031(4); Rh1-C12 = 2.028(6); Rh1-C21 = 2.173(6); Rh1-C22 = 2.195(6); Rh1-C25 = 2.097(6); Rh1$\mathrm{C} 26=2.134(5) ; \mathrm{N} 1-\mathrm{C} 12=1.362(8) ; \mathrm{N} 2-\mathrm{C} 12=1.384(8), \mathrm{N} 1-\mathrm{C} 12-\mathrm{N} 2=102.7(5) ; \mathrm{C} 12-\mathrm{Rh} 1-$ $\mathrm{O} 1$ = 89.9(2); for 3: Rh1-O1 = 2.152(3); Rh1-C12 = 2.029(3); Rh1-C21 = 2.178(6); Rh1-C22 = 2.198(3); Rh1-C25 = 2.095(4); Rh1-C26 = 2.109(4); N1-C12 = 1.355(4); N2-C12 = 1.347(4), N1-C12-N2 = 104.9(3); C12-Rh1-O1 = 84.64(12); for 4: Rh1-O1 = 2.212(3); Rh1$\mathrm{C} 12=2.012(5) ; \mathrm{Rh} 1-\mathrm{C} 21=2.175(5) ; \mathrm{Rh} 1-\mathrm{C} 22=2.225(5) ; \mathrm{Rh} 1-\mathrm{C} 25=2.078(5) ; \mathrm{Rh} 1-\mathrm{C} 26=$ 
2.102(5); N1-C12 = 1.358(6); N2-C12 = 1.347(6), N1-C12-N2 = 104.6(4); C12-Rh1-O1 = 81.9(2).

Table 2. Selected metrical and NMR parameters for complexes 1-4.

\begin{tabular}{|c|c|c|c|c|c|c|c|}
\hline Compound & $\begin{array}{c}\mathrm{Rh}-\mathrm{C}_{\mathrm{NHC}} \\
\text { distance }[\AA]\end{array}$ & $\begin{array}{c}\text { Rh-O distance } \\
[\AA]]\end{array}$ & $\begin{array}{c}\text { bite angle } \alpha \\
\text { O-Rh- } C_{N H C}[\mathrm{deg}]\end{array}$ & $\beta$ angle [deg] & $\begin{array}{c}\text { yaw distortion } \\
\theta \text { [deg] }\end{array}$ & $\begin{array}{c}{ }^{13} \mathrm{C} \text { NMR } \\
\delta \mathrm{C}_{\text {carbene }}[\mathrm{ppm}]\end{array}$ & ${ }^{1} J_{\text {Rh-Ccarbene }}[\mathrm{Hz}]$ \\
\hline $1^{26}$ & $2.042(4)$ & I & I & $74.3(2)$ & 1.2 & 181.90 & 52 \\
\hline 2 & $2.028(6)$ & $2.031(4)$ & $89.8(2)$ & $39.0(2)$ & 8.1 & 179.53 & 56 \\
\hline 3 & $2.029(3)$ & $2.152(3)$ & $84.6(1)$ & $45.4(2)$ & 8.0 & 174.26 & 52 \\
\hline 4 & $2.012(5)$ & $2.212(3)$ & $81.9(2)$ & $49.6(2)$ & 11.6 & 178.91 & 51 \\
\hline
\end{tabular}

The trend in the Rh-O bonding strength is correlated with the trend in ligand bite angle, $\mathrm{O}-\mathrm{Rh}-\mathrm{C}_{\mathrm{NHC}}$ (noted $\alpha$ ). Complex 4 displays the most constrained ligand bite angle $\left(\alpha=82.0(2)^{\circ}\right)$; the corresponding metric is intermediate in $3\left(\alpha=84.6(1)^{\circ}\right)$, while 2 displays a ligand bite angle close to the ideal $90^{\circ}$ angle for a square planar geometry $\left(\alpha=89.8(2)^{\circ}\right)$. This suggests an enhanced stability of the chelate ring, which is more relaxed after deprotonation. The angle between the imidazolyl ring plane and the square-planar coordination plane, noted $\beta$, follows the inverse trend as the bite angle (Table 2). The NHC ring is oriented close to perpendicular $\left(\beta=74.3(2)^{\circ}\right)$ in 1 to minimize steric repulsion with the other ligands in the $x, y$ square-plane, but this angle decreases significantly as a result of ligand chelation to reach $39.0(2)^{\circ}$ in $\mathbf{2}$.

The yaw distortion angle, $\theta$ (Table 2), was first introduced by Crabtree and coworkers ${ }^{49}$ to reflect the in-plane tilting of the $\mathrm{NHC}$ ligand due to ring strain imposed by chelation in bidentate $\mathrm{NHC}$ species. Here, the yaw angle values for $\mathbf{2}$ and $\mathbf{3}\left(\mathrm{ca} .8^{\circ}\right)$ are in the expected range for mesityl-substituted NHCs engaged in a 6-membered ring chelate. ${ }^{49,50}$ This value is much higher in comparison to that of $\mathbf{1}\left(\theta=1.2^{\circ}\right)$ where no ring strain is imposed as expected. ${ }^{26,28}$ The yaw distortion is even more pronounced in $4\left(\theta=11.6^{\circ}\right)$, which we attribute to increased steric pressure due to the presence of the $\mathrm{BF}_{3}$ moiety and the more constrained bite angle. Nevertheless, Crabtree has shown $^{49}$ that yaw distortions do not seem to impact significantly the donation properties of NHCs, which is reflected here by typical Rh- $\mathrm{C}_{\mathrm{NHC}}$ bond distances (ca. $2.028 \AA$, Table 2 ) and ${ }^{13} \mathrm{C}\left\{{ }^{1} \mathrm{H}\right\}$ NMR carbene signal values $\left(\delta=174-182 \mathrm{ppm},{ }^{1} J_{\mathrm{Rh}-\mathrm{C}}=51-\right.$ $56 \mathrm{~Hz}$ ) which do not vary significantly across the series, and without a clear trend (see Table 2). Note that computational analyses from Dorta and coworkers suggested correlation between NHC in-plane tilting and the chemical shift of the carbene carbon in $\operatorname{Ir}(\mathrm{NHC})(\mathrm{COD}) \mathrm{X}$ species, yet on a larger yaw angle range $\left(\theta=0^{\circ}-30^{\circ}\right) .{ }^{51}$

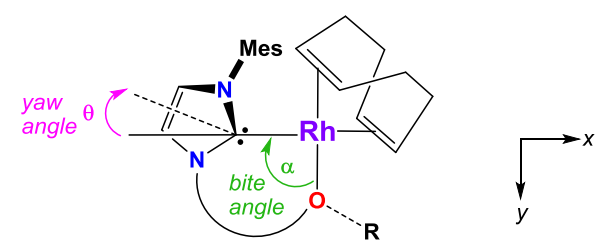

Figure 2. Schematic representation of the geometric descriptors: ligand bite angle $(\alpha)$ and in-plane distortion (yaw angle $\theta$ ) as a result of ligand chelation to the square-planar $\mathrm{Rh}(\mathrm{I})$ center.
The $\mathrm{Rh}-\mathrm{C}_{\mathrm{COD}}$ bond distances in trans position with respect to the NHC ligand (2.173(6) and 2.195(6) $\AA$ in 2; 2.178(4) and 2.199(6) $\AA$ in $3 ; 2.175(5)$ and $2.225(5) \AA$ in 4$)$ are slightly elongated compared to those trans to the oxygenated groups (2.097(6) and 2.134(5) $\AA$ in 2; 2.095(4) and 2.109(3) $\AA$ in 3; 2.078(5) and 2.102(5) $\AA$ in 4), which is in agreement with the stronger $\sigma$ donation of the NHC groups compared to the oxygenated moieties. The higher trans influence of the carbene versus oxygen donors is also reflected by the increased olefinic cis $\mathrm{C} 25=\mathrm{C} 26$ bond lengths (1.403(9) Å in 2, 1.393(7) $\AA$ in 3; 1.406(8) $\AA$ in 4$)$ as compared with the $\mathrm{C} 21=\mathrm{C} 22$ bond lengths $(1.379(8) \AA$ in $2 ; 1.358(8) \AA$ in $3 ; 1.357(8) \AA$ in 4 ), which are alike for the whole series of these Rh COD species.

In summary, the analysis of the structural properties in complexes 1-4 shows analogous $\mathrm{Rh}(\mathrm{I})$-carbene interactions but high disparities in the rhodium-oxygen bonding which are directly correlated with chelate geometry variations $(\alpha, \beta$ and $\theta$ angles). Note that these structural trends are independent from the charge of the complex since the metrical data for the cationic species, $\mathbf{3}$, are comprised between those of the two neutral species $\mathbf{2}$ and $\mathbf{4}$.

\section{Catalyst screening}

At first sight, compounds 1-4 might seem very similar. All these 16-electron complexes feature a tetra-coordinated $\mathrm{Rh}(\mathrm{I})$ center bound to a COD moiety and to a NHC ligand. Furthermore, the first coordination sphere in compounds 2-4 is alike, with one COD ligand and one $\mathrm{O}, \mathrm{C}_{\mathrm{NHC}}$ chelating ligand. Nevertheless, the subtle changes in the nature of the O-containing pendant arm are found to be responsible for the substantial differences in the catalytic activity of these compounds.

$\mathrm{Rh}(\mathrm{I}) \mathrm{NHC}$ species have been used as catalysts in hydrosilylation processes of carbonyls ${ }^{22,52,53}$, alkynes ${ }^{54-57}$ and alkenes. ${ }^{21-23}$ Encouraged by these precedents, we decided to evaluate which structural factors are critical for the alkene hydrosilylation performances of the present family of catalysts. The $\mathrm{Rh}(\mathrm{I})$ species 1-4 were thus tested in the model reaction between 3,3dimethyl-1-butene (TBE) and an industrially relevant nonactivated tertiary silane, namely 1,1,1,3,5,5,5heptamethyltrisiloxane $\left(\mathrm{MD}^{\mathrm{H}} \mathrm{M}\right)$. The reactions were monitored by ${ }^{1} \mathrm{H}$ NMR in THF- $\mathrm{d}_{8}$ under the same experimental conditions (r.t., 1.0 mol\% of catalyst). As shown in Table 3, complex 2 displays the highest activity (100\% yield within $15 \mathrm{~min}$ ), while 3 and 4 required $5 \mathrm{~h}$ and $40 \mathrm{~h}$ respectively to reach $>90 \%$ yield. Complex 1 was the slowest catalyst at r.t. and required heating $\left(50{ }^{\circ} \mathrm{C}\right)$ to achieve complete hydrosilylation under a reasonable 
time scale $(20 \mathrm{~h})$. Importantly, under these experimental conditions, the anti-Markovnikov hydrosilylation product was obtained with $100 \%$ selectivity in all cases (as confirmed by mass balance analysis), without evidence of parasitic dehydrogenative silylation which was previously seen in other $\mathrm{Rh}(\mathrm{I})-\mathrm{NHC}$ catalyzed alkene hydrosilylation reactions. ${ }^{21}$ Additionally, we compared the alkene hydrosilylation activity of 1-4 with two other $\mathrm{Rh}(\mathrm{I})$ complexes, namely with $[\mathrm{Rh}(\mathrm{COD}) \mathrm{Cl}]_{2}$ and $\mathrm{RhCl}\left(\mathrm{PPh}_{3}\right)_{3}$, to demonstrate the beneficial effect of the bifunctional $\mathrm{NHC}$ ligand. Interestingly, $[\mathrm{Rh}(\mathrm{COD}) \mathrm{Cl}]_{2}$ had no catalytic activity under this set of experimental conditions, even when the temperature was raised to $50{ }^{\circ} \mathrm{C}$, (versus $>90 \%$ yield for 1 which is the poorest catalyst of the Rh-NHC series), while $\mathrm{RhCl}\left(\mathrm{PPh}_{3}\right)_{3}$ exhibited no activity at r.t. but good activity at $50{ }^{\circ} \mathrm{C}$ (>99\% conversion after $24 \mathrm{~h}$ at $50{ }^{\circ} \mathrm{C}$ ). Only at $100{ }^{\circ} \mathrm{C}$ did $[\mathrm{Rh}(\mathrm{COD}) \mathrm{Cl}]_{2}$ and $\mathrm{RhCl}\left(\mathrm{PPh}_{3}\right)_{3}$ achieve similar activity to $\mathbf{2}(>90 \%$ conversion after $1 \mathrm{~h}$ at $100^{\circ} \mathrm{C}$ ), demonstrating the positive role of $\mathrm{NHC}$ ligands to reach active $\mathrm{Rh}(\mathrm{I})$ catalysts even at room temperature.

Table 3. Catalyst screening for the hydrosilylation of 3,3-dimethylbut-1-ene with $\mathrm{MD}^{\mathrm{H}} \mathrm{M}^{\mathrm{a}}{ }^{\mathrm{a}}$

\begin{tabular}{|c|c|c|}
\hline \multirow{3}{*}{\multicolumn{2}{|c|}{ 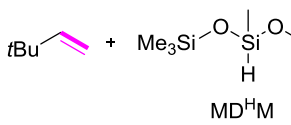 }} & $1.0 \mathrm{~mol} \%$ cat. \\
\hline & & THF, r.t. \\
\hline & & \\
\hline Entry & Catalyst & time to reach $>90 \%$ y \\
\hline 1 & 1 & $\begin{array}{l}>40 \mathrm{~h} \text { at r.t. } \\
20 \mathrm{~h} \text { at } 50^{\circ} \mathrm{C}\end{array}$ \\
\hline 2 & 2 & $0.25 \mathrm{~h}$ \\
\hline 3 & 3 & $5 \mathrm{~h}$ \\
\hline 4 & 4 & $40 \mathrm{~h}$ \\
\hline
\end{tabular}

Conditions: 3,3-dimethylbut-1-ene (0.45 mmol, 1.0 eq.), MD ${ }^{\mathrm{H} M}(0.45 \mathrm{mmol}, 1.0$ eq.), durene as internal standard (1.0 eq.), catalyst ( 1.0 mol\%), THF-d 8 ( $0.5 \mathrm{~mL})$ Conversions of starting materials and formation of product are based on ${ }^{1} \mathrm{H}$ NMR

From this first set of experiments, several conclusions can be drawn:

(i) the NHC ligand enhances the catalytic alkene hydrosilylation performances of $\mathrm{Rh}(\mathrm{I})$

(ii) subtle stereo-electronic effects have a dramatic impact on the catalysts' activity

(iii) the global charge of the complex is not a critical factor for catalysis since the activity of the cationic species $\mathbf{3}$ is average between that of $\mathbf{2}$ and $\mathbf{4}$, both of which being neutrally charged

(iv) oxygen binding to $\mathrm{Rh}$ is beneficial since complexes 2-4 are much more active than 1

(v) the stronger the oxygen binding to $\mathrm{Rh}$, the better the catalysis since the activity trend $\mathbf{2}>\mathbf{3}>\mathbf{4}>\mathbf{1}$ is directly correlated to the Rh-O metric.

Note that hemilabile coordination of $\mathrm{N}$ - or O-donors attached to functionalized NHCs can have a drastic impact in the catalytic performances of $\mathrm{Rh}$ or $\mathrm{Ir}$ complexes (either beneficial or detrimental depending on the systems and catalytic reactions considered). ${ }^{33,35,55,58-60}$ The decoordination of the oxygen arm in complex $\mathbf{2}$ is unlikely, due to the strong interaction between $\mathrm{Rh}(\mathrm{I})$ and the charged alkoxy group. In the case of complexes $\mathbf{3}$ and 4 the decoordination of the oxygenated side-arm might occur in the course of catalysis, yet ${ }^{1} \mathrm{H}$ NMR studies on precatalyst 4, featuring inequivalent diastereotopic $\mathrm{N}-\mathrm{CH}_{2}$ protons, tend to suggest that fluxional hemilabile coordination is not occurring at room temperature.

Optimization of the reaction conditions with catalyst $\mathbf{2}$ shows that excellent yields (94\%) can be reached at room temperature with catalyst loading as low as $0.01 \mathrm{~mol} \%$ and without any additives $($ TON $=9400,100 \%$ selectivity, kinetic profiles shown in Figure S17).

\section{Alkene hydrosilylation scope}

With the best catalyst in hands, we then performed a substrate screening for the catalytic hydrosilylation of terminal alkenes with $M D^{H} M$. The results from Table 4 show that excellent catalytic performances were achieved, with excellent selectivity towards the hydrosilylation product. For simple unfunctionalized terminal alkenes, $0.1 \mathrm{~mol} \%$ of 2 can be used to convert them to the corresponding anti-Markovnikov hydrosilylation products (entries $1-3$ ) in $>92 \%$ yield at r.t after 5 h. However, when functionalized alkenes were used, the catalyst loading had to be increased to $1.0 \mathrm{~mol} \%$ to obtain products in $>90 \%$ yields within $24 \mathrm{~h}$. Entry 4 illustrates how the presence of a phenyl group slows down the hydrosilylation rate in styrene to $13 \%$ after $5 \mathrm{~h}$ compared to TBE, which reached $>95 \%$ product formation in $5 \mathrm{~h}$ (Table 4 , entry 4 ). This surprising result is in sharp contrast to previously reported work, where $>95 \%$ of styrene conversion was observed in the presence of a $\mathrm{Rh}(\mathrm{I})-\mathrm{NHC}$ catalyst and various silane counterparts, but at the cost of low chemoselectivity. ${ }^{21}$ While the negative effect of the phenyl group on the product formation was also seen for longer chain allyl benzene (entry 5) and 4-phenyl-1-butene (entry 6) hydrosilylation products ( $63 \%$ and $83 \%$ of respective yields after $5 \mathrm{~h}$ ), in both cases $>93 \%$ hydrosilylation yields were obtained when extending the reaction time to $24 \mathrm{~h}$. 
Table 4. Catalytic performances of cat. $\mathbf{2}$ for the hydrosilylation of various terminal alkenes with $\mathrm{MD}^{\mathrm{H}} \mathrm{M}$. $^{\mathrm{a}}$

cat. loading (mol\%)

Conditions: alkene $(0.45 \mathrm{mmol}, 1.0$ eq. $), \mathrm{MD}^{\mathrm{H} M}(0.45 \mathrm{mmol}, 1.0$ eq. $)$, mesitylene as internal standard (1.0 eq.), catalyst (0.1-1.0 mol\%), THF $(500 \mu \mathrm{L})$. Conversions of starting materials and formation of product are based on GC. The yields in brackets correspond to the isolated yields at the end of the reaction.

Next, we tested allyl ethers, which are known to be capricious substrates as competing $\mathrm{C}-\mathrm{O}$ bond cleavage and $\mathrm{C}=\mathrm{C}$ bond isomerization are often observed. ${ }^{61-64}$ Similarly to linear alkenes containing a phenyl group (entries 4-6), benzyl allyl ether (entry 7) led to only $79 \%$ expected product after $5 \mathrm{~h}$, but reached $94 \%$ yield after $24 \mathrm{~h}$. Two other allyloxy group containing substrates, allyloxytrimethylsilane (entry 8 ) and allyl glycidyl ether (entry 9), were well tolerated by the catalyst $\mathbf{2}$, as $>90 \%$ yields were reached after $5 \mathrm{~h}$. As a final example of functionalized alkene, we chose ethyl-4-pentenoate (entry 10), which demonstrated exclusive chemoselectivity towards $\mathrm{C}=\mathrm{C}$ bond hydrosilylation product ( $>95 \%$ yield in $5 \mathrm{~h}$ ) under current reaction conditions. It should be noted that, throughout the course of hydrosilylation reactions, internal isomers of isomerizable substrates were observed at short reaction times $(<5 \mathrm{~h})$. These isomers are converted into the linear hydrosilylation product at long reaction time $(24 \mathrm{~h})$, indicating that olefin isomerization occurs hand in hand with $\alpha$-olefin hydrosilylation in the course of the reaction (Scheme 3). Overall, catalyst $\mathbf{2}$ is a versatile alkene hydrosilylation catalyst under mild conditions (r.t., no additives) with excellent chemoselectivity (no O-silylation or dehydrogenative silylation) and regioselectivity (only the antiMarkovnikov product). These catalytic performances are remarkable since numerous Rh-based alkene hydrosilylation catalytic systems suffer from regio- and/or chemoselectivity issues. ${ }^{21,22,65-67}$

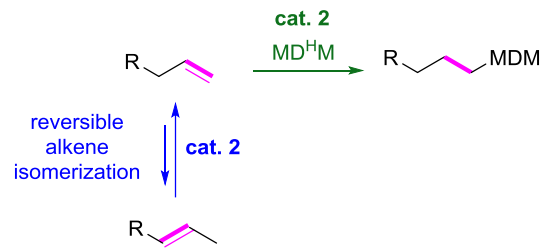

Scheme 3. Catalyst $\mathbf{2}$ promotes at the same time reversible olefin isomerization (blue) and regio- and chemo-selective $\alpha$-olefin hydrosilylation (green).

In order to get some hints on the active species, we investigated the stoichiometric reaction between a THF solution of complex 2 and a THF solution of $\mathrm{MD}^{\mathrm{H}} \mathrm{M}$. Upon mixing at $0^{\circ} \mathrm{C}$, an instantaneous color change from light yellow to dark orange is observed. ${ }^{1} \mathrm{H}$ NMR reaction monitoring shows the quick formation of a rhodium hydride intermediate species with a characteristic resonance at $\delta=-13.04 \mathrm{ppm}\left({ }^{1} J_{\mathrm{Rh}-\mathrm{H}}=23.8 \mathrm{~Hz}\right.$, see Figure S18). However this intermediate is unstable at r.t. and degrades into a complex mixture of unidentified species, which prevented further characterization of this transient compound. The involvement of a $\mathrm{Rh}-\mathrm{H}$ intermediate, presumably formed via oxidative addition of the $\mathrm{Si}-\mathrm{H}$ moiety from MDHM onto $\mathrm{Rh}(\mathrm{I})$, is not surprising since rhodium hydrides are known to be efficient alkene isomerization catalysts. ${ }^{68-70}$

\section{Tandem internal alkene isomerization-hydrosilylation}

The transient formation of internal alkene isomers in the course of the catalytic tests described above with isomerizable $\alpha$-olefin substrates suggested that catalyst $\mathbf{2}$ could be used to functionalize internal olefins. In our attempt to valorize substrates potentially relevant in silicon industry, we thus tested internal octenes as tandem isomerization-hydrosilylation partners with $\mathrm{MDH}^{\mathrm{H} M}$ (Table 5). At 1.0 mol\% catalyst loading, complex $\mathbf{2}$ was able to effectively tandem isomerizehydrosilylate in $5 \mathrm{~h}$ 2-trans- (entry 1), 3-trans- (entry 2), 4-trans(entry 3 ) and 4-cis-octene (entry 4) to the corresponding linear product in $>92 \% \mathrm{GC}$ yield in all cases. To mimic the industrially suitable conditions of using low-value internal olefins to generate linear silicon products, we demonstrated the possibility of using mixtures of the four previously mentioned internal octenes to generate the linear $\mathrm{MD}^{\mathrm{H}} \mathrm{M}$ derivative in $97 \%$ yield in only $5 \mathrm{~h}$ at room temperature (entry 5). These performances rivals those of the best catalysts described in literature, $7,10-12,17$ and demonstrate the possibility of using industrially-relevant mixtures of internal alkenes with the nonactivated silane, $M D^{H} \mathrm{M}$, to form linear products in excellent yields.

The above results suggest that internal alkenes far less reactive towards direct hydrosilylation than terminal olefins. In the case 
of cyclic internal olefins where isomerization cannot lead to exocyclic $\mathrm{C}-\mathrm{C}$ double bond in terminal position, the results were found dependent on the ring strain. Cat. $\mathbf{2}$ was found inactive to hydrosilylate cyclooctene, even after prolonged time, while treatment of norbornene with $\mathrm{MD}^{\mathrm{H}} \mathrm{M}$ under the same reaction conditions resulted in fast hydrosilylation with $100 \%$ stereoselectivity for the exo-isomer (Table 5, entries 6 and 7). The aptitude of norbornene to be easily hydrosilylated, even under relatively mild conditions, is known, but most catalysts generally lead to a mixture of exo and endo isomers. ${ }^{14,71}$

Table 5. Catalytic performances of cat. 2 for the tandem isomerization/hydrosilylation of various internal alkenes with $\mathrm{MD}^{\mathrm{H}} \mathrm{M}{ }^{\mathrm{a}}$

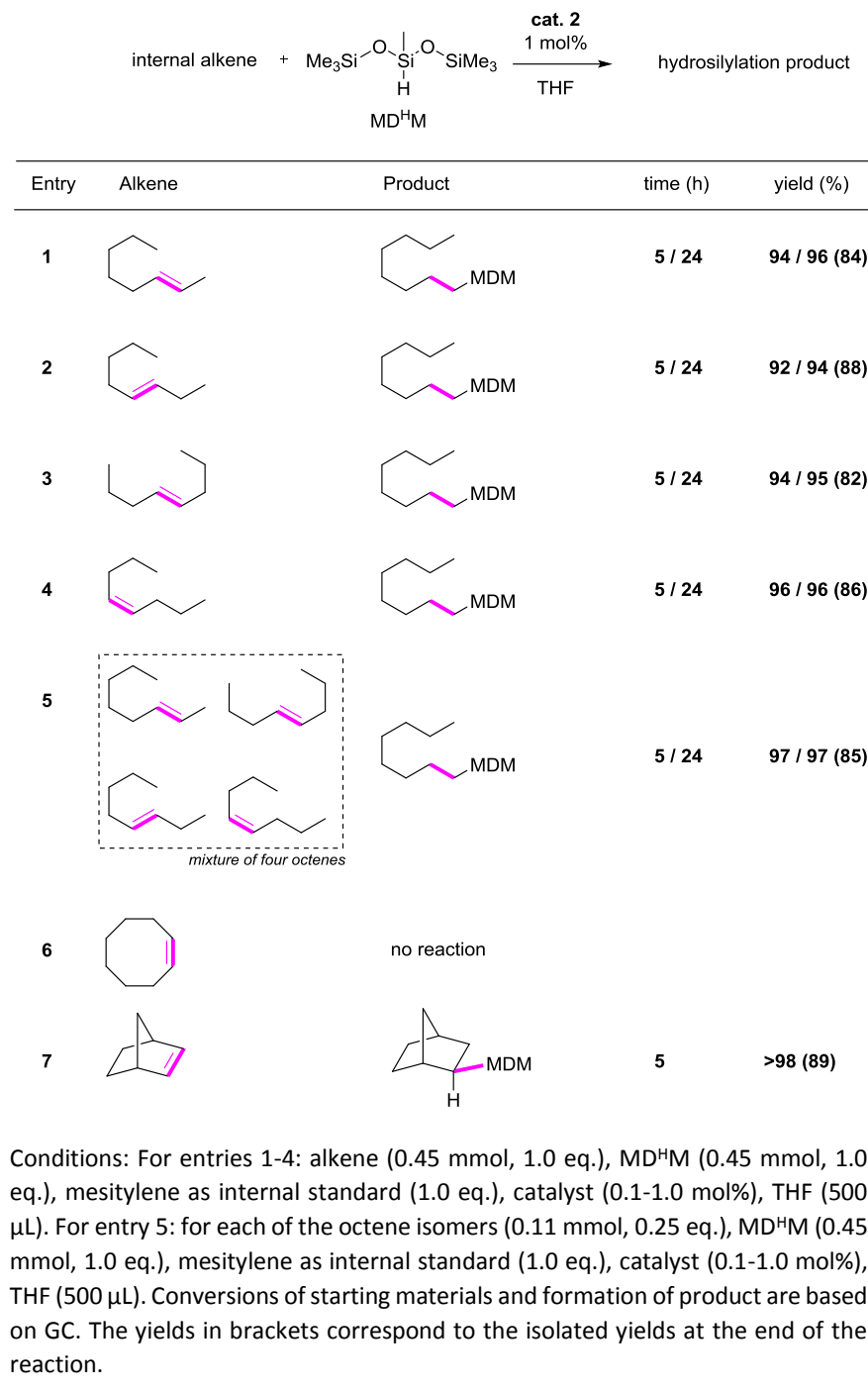

\section{Conclusions}

This work demonstrates that the catalytic performances of metal-NHC species can be significantly affected by subtle stereo-electronic effects. This was illustrated by a series of four closely related rhodium(I) complexes, all featuring a COD ligand and an oxygen-functionalized NHC ligand. These complexes were tested in a model catalytic reaction: the hydrosilylation of terminal alkenes with a non-activated tertiary silane. The results show that the global charge of the complex (cationic vs neutral) is not a critical factor for catalysis. However, this study suggests that the stronger the oxygen binding to Rh, the better the catalytic performances since the activity trend is directly correlated to the Rh-O metric. Excellent conversions can be reached with the most active catalyst $\mathbf{2}$ for a scope of terminal alkenes under mild conditions (room temperature, no additives, catalyst loading as low as $0.01 \mathrm{~mol} \%$ ) with exclusive regio- and chemo-selectivity. Furthermore, $\mathbf{2}$ exhibits excellent tandem isomerization-hydrosilylation catalytic performances for the selective terminal hydrosilylation of mixtures of internal alkenes, opening attractive perspectives for the challenging valorization of unconventional olefin feedstocks.

\section{Conflicts of interest}

There are no conflicts to declare.

\section{Acknowledgements}

We thank the "Centre de diffractométrie Henri Longchambon, Université de Lyon", and in particular Erwan Jeanneau for the single-crystal X-ray diffraction analyses. This research was funded by the "Programme Avenir Lyon Saint-Etienne de I'Université de Lyon" as part of the "Investissements d'Avenir" program (ANR-11-IDEX-0007), the CNRS MOMENTUM 2017 program and the SINCHEM program. SINCHEM is a Joint Doctorate program selected under the Erasmus+ Action 1 Program (FPA2013-0037).

\section{Notes and references}

1

2

3

4

5 6 7
W. Keim, Angew. Chemie - Int. Ed., 2013, 52, 12492-12496. O. O. James, S. Mandal, N. Alele, B. Chowdhury and S. Maity, Fuel Process. Technol., 2016, 149, 239-255. H. Sommer, F. Juliá-Hernández, R. Martin and I. Marek, ACS Cent. Sci., 2018, 4, 153-165.

A. Vasseur, J. Bruffaerts and I. Marek, Nat. Chem., 2016, 8, 209-219.

Y. Nakajima and S. Shimada, RSC Adv., 2015, 5, 2060320616.

J. Sun and L. Deng, ACS Catal., 2016, 6, 290-300.

I. Buslov, F. Song and X. Hu, Angew. Chemie - Int. Ed., 2016, 55, 12295-12299.

I. Buslov, J. Becouse, S. Mazza, M. Montandon-Clerc and X. Hu, Angew. Chemie - Int. Ed., 2015, 54, 14523-14526.

B. B. Sarma, J. Kim, J. Amsler, G. Agostini, C. Weidenthaler, N. Pfänder, R. Arenal, P. Concepción, P. Plessow, F. Studt and G. Prieto, Angew. Chemie - Int. Ed., 2020, 132, 58555864.

X. Jia and Z. Huang, Nat. Chem., 2016, 8, 157-161.

S. Azpeitia, A. Rodriguez-Dieguez, M. A. Garralda and M. A. Huertos, ChemCatChem, 2018, 10, 2210-2213.

S. Azpeitia, M. A. Garralda and M. A. Huertos, ChemCatChem, 2017, 9, 1901-1905. 
13 T. K. Meister, K. Riener, P. Gigler, J. Stohrer, W. A. Herrmann and F. E. Kühn, ACS Catal., 2016, 6, 1274-1284. D. Noda, A. Tahara, Y. Sunada and H. Nagashima, J. Am. Chem. Soc., 2016, 138, 2480-2483. C. Chen, M. B. Hecht, A. Kavara, W. W. Brennessel, B. O. Mercado, D. J. Weix and P. L. Holland, J. Am. Chem. Soc., 2015, 137, 13244-13247.

C. C. H. Atienza, T. Diao, K. J. Weller, S. A. Nye, K. M. Lewis, J. G. P. Delis, J. L. Boyer, A. K. Roy and P. J. Chirik, J. Am. Chem. Soc., 2014, 136, 12108-12118.

17 M. Jakoobi, V. Dardun, L. Veyre, V. Meille, C. Camp and C. Thieuleux, J. Org. Chem., 2020, 85, 11732-11740. I. E. Markó, S. Stérin, O. Buisine, G. Mignani, P. Branlard, B. Tinant and J. P. Declercq, Science (80-. )., 2002, 298, 204206.

P. Zak, M. Bołt, M. Kubicki and C. Pietraszuk, Dalton Trans., 2018, 47, 1903-1910.

A. M. Ruiz-Varilla, E. A. Baquero, G. F. Silbestri, C. GonzalezArellano, E. De Jesús and J. C. Flores, Dalton Trans., 2015, 44, 18360-18369. B. J. Truscott, A. M. Z. Slawin and S. P. Nolan, Dalton Trans., 2013, 42, 270-276. A. J. Huckaba, T. K. Hollis and S. W. Reilly, Organometallics, 2013, 32, 6248-6256. J. Li, J. Peng, Y. Bai, G. Lai and X. Li, J. Organomet. Chem., 2011, 696, 2116-2121.

B. P. Maliszewski, N. V. Tzouras, S. G. Guillet, M. Saab, M. Beliš, K. Van Hecke, F. Nahra and S. P. Nolan, Dalton Trans., 2020, 49, 14673-14679.

5 R. Srivastava, E. A. Quadrelli and C. Camp, Dalton Trans., 2020, 49, 3120-3128.

R. Srivastava, R. Moneuse, J. Petit, P.-A. A. Pavard, V. Dardun, M. Rivat, P. Schiltz, M. Solari, E. Jeanneau, L. Veyre, C. Thieuleux, E. A. Quadrelli and C. Camp, Chem. - A Eur. J., 2018, 24, 4361-4370.

V. Dardun, L. Escomel, E. Jeanneau and C. Camp, Dalton Trans., 2018, 47, 10429-10433.

J. Petit, P.-A. Pavard and C. Camp, Mendeleev Commun., 2021, 31, in press.

R. R. Schrock and J. D. Fellmann, J. Am. Chem. Soc., 1978, 100, 3359-3370.

R. C. Clark and J. S. Reid, Acta Crystallogr. Sect. A Found. Crystallogr., 1995, 51, 887-897.

A. Altomare, M. C. Burla, M. Camalli, G. L. Cascarano, C. Giacovazzo, A. Guagliardi, A. G. G. Moliterni, G. Polidori and R. Spagna, J. Appl. Crystallogr., 1999, 32, 115-119.

P. W. Betteridge, J. R. Carruthers, R. I. Cooper, K. Prout and D. J. Watkin, J. Appl. Crystallogr., 2003, 36, 1487-1487.

E. Peris, Chem. Rev., 2018, 118, 9988-10031.

A. Bartoszewicz, R. Marcos, S. Sahoo, A. K. Inge, X. Zou and B. Martín-Matute, Chem. - A Eur. J., 2012, 18, 1451014519.

G. González Miera, E. Martínez-Castro and B. MartínMatute, Organometallics, 2018, 37, 636-644.

S. Lassalle, R. Jabbour, P. Schiltz, P. Berruyer, T. K.

Todorova, L. Veyre, D. Gajan, A. Lesage, C. Thieuleux and C. Camp, J. Am. Chem. Soc., 2019, 141, 19321-19335.
S. Lassalle, R. Jabbour, I. Del Rosal, L. Maron, E. Fonda, L. Veyre, D. Gajan, A. Lesage, C. Thieuleux and C. Camp, J. Catal., 2020, 392, 287-301.

A. Antiñolo, M. F. Lappert, A. Singh, D. J. W. Winterborn, L. M. Engelhardt, C. L. Raston, A. H. White, A. J. Carty and N. J. Taylor, J. Chem. Soc., Dalt. Trans., 1987, 0, 1463-1472. C. H. Winter, X. X. Zhou and M. J. Heeg, Inorg. Chem., 1992, 31, 1808-1815.

A. Antiñolo, M. Fajardo, R. Gil-Sanz, C. López-Mardomingo, P. Martín-Villa, A. Otero, M. M. Kubicki, Y. Mugnier, S. EI Krami and Y. Mourad, Organometallics, 1993, 12, 381-388. C. Camp, L. Maron, R. G. Bergman and J. Arnold, J. Am. Chem. Soc., 2014, 136, 17652-17661.

C. M. Álvarez, R. Carrillo, R. García-Rodríguez and D. Miguel, Chem. - A Eur. J., 2013, 19, 8285-8293.

A. J. Cresswell, S. G. Davies, P. M. Roberts and J. E. Thomson, Chem. Rev., 2015, 115, 566-611.

E. Tomat, L. Cuesta, V. M. Lynch and J. L. Sessler, Inorg Chem., 2007, 46, 6224-6226.

R. Bini, C. Chiappe, F. Marchetti, G. Pampaloni and S. Zacchini, Inorg. Chem., 2010, 49, 339-351.

F. Marchetti, G. Pampaloni and S. Zacchini, J. Fluor. Chem., 2010, 131, 21-28.

\section{6, 128, 3124-3125.} 2006, 128, 9642-9643.

H. L. Chin, C. D. Incarvito and R. H. Crabtree, Organometallics, 2006, 25, 6099-6107.

M. Poyatos, J. A. Mata and E. Peris, Chem. Rev., 2009, 109, 3677-3707.

G. Sipos, A. Ou, B. W. Skelton, L. Falivene, L. Cavallo and R. Dorta, Chem. - A Eur. J., 2016, 22, 6939-6946.

G. Lázaro, F. J. Fernández-Alvarez, J. Munárriz, V. Polo, M. Iglesias, J. J. Pérez-Torrente and L. A. Oro, Catal. Sci. Technol., 2015, 5, 1878-1887.

B. Yiğit, M. Yiğit and I. Özdemir, Inorganica Chim. Acta, 2017, 467, 75-79.

J. P. Morales-Cerón, P. Lara, J. López-Serrano, L. L. Santos, V. Salazar, E. Álvarez and A. Suárez, Organometallics, 2017, 36, 2460-2469.

M. V. Jiménez, J. J. Pérez-Torrente, M. I. Bartolomé, V. Gierz, F. J. Lahoz and L. A. Oro, Organometallics, 2008, 27, 224-234.

L. Busetto, M. C. Cassani, C. Femoni, M. Mancinelli, A. Mazzanti, R. Mazzoni and G. Solinas, Organometallics, 2011, 30, 5258-5272.

O. Bartlewicz, M. Jankowska-Wajda and H. Maciejewski, Catalysts, 2020, 10, 608.

G. Mancano, M. J. Page, M. Bhadbhade and B. A. Messerle, Inorg. Chem., 2014, 53, 10159-10170.

. Aliaga-Lavrijsen, M. Iglesias, A. Cebollada, K. Garcés, N. García, P. J. Sanz Miguel, F. J. Fernández-Alvarez, J. J. PérezTorrente and L. A. Oro, Organometallics, 2015, 34, 23782385. Herrmann and F. E. Kühn, Inorg. Chem., 2014, 53, 12767- 
Journal Name

12777.

61 Z. V Belyakova, M. G. Pomerantseva, L. A. Efimova, E. A. Chernyshev and P. A. Storozhenko, Russ. J. Gen. Chem., 2010, 80, 728-733.

62 M. Igarashi, T. Kobayashi, K. Sato, W. Ando, T. Matsumoto, S. Shimada, M. Hara and H. Uchida, J. Organomet. Chem., 2013, 725, 54-59.

63 M. Igarashi, T. Matsumoto, T. Kobayashi, K. Sato, W. Ando, S. Shimada, M. Hara and H. Uchida, J. Organomet. Chem., 2014, 749, 421-427.

64 C. L. Rock and R. J. Trovitch, Dalton Trans., 2019, 48, 461467.

65 J. Li, J. Peng, G. Zhang, Y. Bai, G. Lai and X. Li, New J. Chem., 2010, 34, 1330-1334.

66 W. Lu, C. Li, X. Wu, X. Xie and Z. Zhang, Organometallics, 2020, 39, 3780-3788.

67 J. Li, J. Peng, D. Wang, Y. Bai, J. Jiang and G. Lai, J. Organomet. Chem., 2011, 696, 263-268.

68 S. Y. Y. Yip and C. Aïssa, Angew. Chemie Int. Ed., 2015, 54, 6870-6873.

69 J. F. Biellmann and M. J. Jung, J. Am. Chem. Soc., 1968, 90, 1673-1674.

70 T. C. Morrill and C. A. D'Souza, Organometallics, 2003, 22, 1626-1629.

71 R. Bandari and M. R. Buchmeiser, Catal. Sci. Technol., 2012, 2, 220-226. 